\title{
NUMERICAL ANALYSIS OF ELEVATED FRAMED STAGING SHALLOW TANK BY NEWMARK'S STEP-BY-STEP METHOD
}

\author{
Dr. Pravin B.Waghmare \\ Civil Engineering Dept., A.S. Polytechnic/ MSBTE, Mumbai, Wardha (M.S), India
}

\begin{abstract}
Water tank is a life line structure, are extensively used in water supply facilities, oil, gas and nuclear power plants, for storage of variety of liquid material, e.g. Oil, LNG.Due to earthquake critical damage to elevated R. C. C. tanks are found. In the present work, a $50 \mathrm{~m}^{3}$ water tank has been analyzed for $x$-direction earthquake ground motion for fixed and an isolation system (Elastomeric bearing) is used to reduce the behavior of the basic response e.g. base shear, time period, tower drift, flexibility, of the elevated R. C. C. tanks. For solving complicated equation of motion for a coupled analysis a Newmark's step by step iteration method is used. After detailed analysis of $50 \mathrm{~kL}$ water tank, due to isolation base shear reduced significantly and the sloshing displacement increases as compared to non-isolated tank, also increase in isolation period from $2 \mathrm{sec}$ to $4 \mathrm{sec}$, base shear reduced significantly.
\end{abstract}

Keywords: base shear, Elastomeric bearing, flexibility, R.C.C.tanks, time period, tower drift

Cite this Article: Dr. Pravin B. Waghmare, Numerical Analysis of Elevated Framed Staging Shallow Tank by Newmark's Step-By-Step Method, International Journal of Advanced Research in Engineering and Technology, 10 (2), 2019, pp 22-33.

http://iaeme.com/Home/issue/IJARET?Volume=10\&Issue=2

\section{INTRODUCTION}

One of the most important lifeline structure used for storing liquefied material is R.C.C.water tank which is commonly used as storing various liquid material e.g. water, oil, LPG and hazardous chemicals. It is reported from last some years that tanks are suffered through heaviest damages due to earthquake, some of the mentioned reports are Bhuj in 2001,Jabalpur in 1997,Latur in 1993,Nigata in 1964,Alaska in 1964,Park Field in 1966,Imperial Country in 1979,Colinga in 1983,Northridge in 1994 and Kocaeli 1999. Due to this fact in recent years, research on base isolation techniques has made significant progress in the reduction of seismic response of liquid storage tanks. Some studies for modelling ground liquid storage tanks and their dynamic response have been performed to acknowledge their reaction [1].

Actually, Housner [2] did his work on water tank and developed a mathematical model in which the water mass of the liquid portion that accelerates with the tank is called as "impulsive"' and the mass near the surface of the tank which exhibits the sloshing movements 
is called as convective mass. Haroun [3,4] modified the Housner's [2] by considering the flexibility of tank wall in the seismic analysis. Chen and Kianoush [5] work on generalised SDOF system for seismic analysis of concrete rectangular liquid storage tanks and compare the results with FEM model, which are more accurate. This study also recommended that the effect of the flexibility of a tank wall should be considered in the calculation of hydrodynamic pressures for concrete rectangular tanks. Kianoush and Ghaemmaghami [6] investigated the behaviour of rectangular concrete water tank by FEM model.Chalhoub and Kelly [7, 8] conclude that the sloshing mass in the tank increases slightly with the decrease of total hydrodynamics pressure due to isolation. Kim and Lee [9] experimentally investigated the response of unidirectional excitation of base isolated water tank water tank and it is found that base isolation is very effective in reducing the response of tank, same results has been narrates by Liang and Tang [10]. Malhotra [11, 12] use different isolation system for reducing the various responses of the tank and suggested that base isolation system is better than the conventional techniques. Shrimali and Jangid $[13,14]$ performed the experiment by considering the interaction effect of the bearing forces with imparting the off-diagonal component in the analysis and it is observed that the seismic response of isolated tank is insensitive to interaction effect of the bearing forces.

\section{MATHEMATICAL MODELLING OF WATER TANK}

\subsection{Governing Equation in Liquid Domain}

In this work, following assumption are made,

i) Fluid is ideal

ii) Fluid is in viscid and incompressible

iii) Fluid follow irrotational flow.

Following momentum equation is used for defining the flow.

$$
u=\frac{\partial \emptyset}{\partial x} v=\frac{\partial \emptyset}{\partial y} \quad w=\frac{\partial \emptyset}{\partial z}
$$

Where, $\varnothing$ - velocity potential $\mathrm{x}, \mathrm{y}, \mathrm{z}$-position vector which is given by

The governing equation of liquid motion is replaced by the Laplace equation.

$$
\frac{\partial u}{\partial x}+\frac{\partial v}{\partial y}+\frac{\partial w}{\partial z}=0 \text { or } \nabla^{2} \emptyset=0
$$

Dynamic boundary condition of the free surface can be represented in general format by following equation which also defines surface sloshing and pressure is assumed to be zero at the water surface with some approximation.

Boundary condition of the fluid-structure interface formula is given by equation $4,[15]$,

$$
\frac{\partial \emptyset}{\partial n}=v n(t)
$$

Where ' $\mathrm{g}$ ' is the acceleration due to gravity and $v n(t)$ is the relative normal fluid velocity at the tank wall at time $(\mathrm{t})$.

\subsection{Formulation of Liquid mass in water tank}

Fig. 1 shows the idealized structural model of elevated R.C.C. liquid storage tank mounted on Laminated Rubber Bearing (with and without Lead). The Elastomeric bearings are placed between the base and foundation of the tank for isolation. The contained continuous liquid mass is modelled as two degrees of freedom and liquid is lumped as convective, and impulsive masses are modelled as $\mathrm{m}_{\mathrm{c}}, \mathrm{m}_{\mathrm{i}}$ respectively. The convective and impulsive masses are modelled as spring having stiffness $\mathrm{k}_{\mathrm{c}}$, and $\mathrm{k}_{\mathrm{i}}$ as shown in fig.1, with damping constants $\mathrm{c}_{\mathrm{c}}$ and $\mathrm{c}_{\mathrm{i}}$, respectively [25]. 


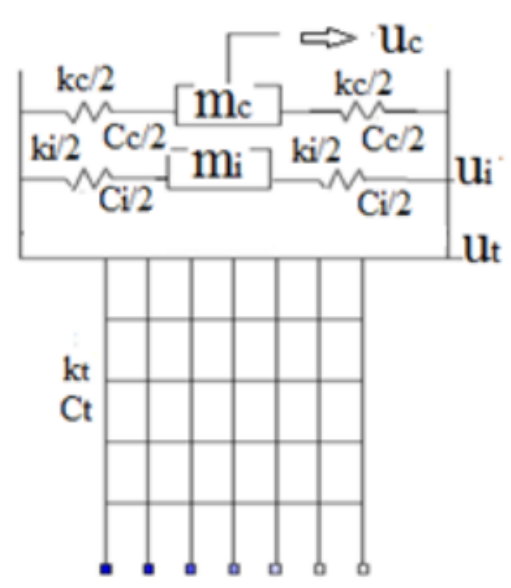

(a)

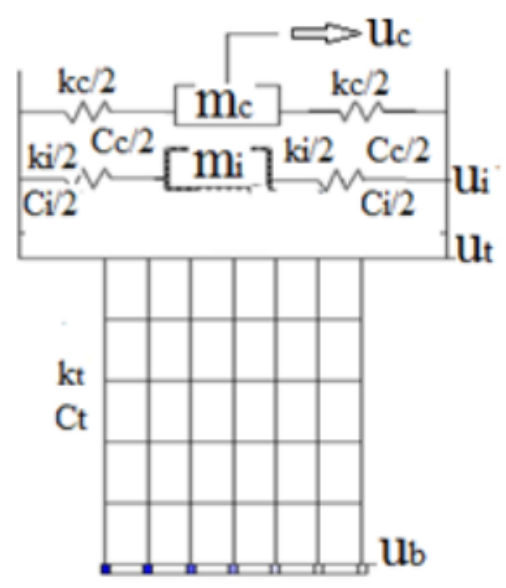

(b)

Figure.1. Structural model of elevated liquid storage R.C.C. tank: (a) non-isolated, (b) With isolation at Bottom of column (isolated model-I) [26].

\subsubsection{Shallow and Slender Tanks [23, 24]}

For a cylindrical storage tank of radius $\mathrm{R}$, containing an incompressible liquid of mass density $\left(\rho_{\mathrm{w}}\right)$ of the liquid. Filled to a depth $\mathrm{H}$, the total mass of liquid is given by.

$\mathrm{m}=\pi \mathrm{R}^{2} \mathrm{H} \rho_{\mathrm{w}}$

\section{Shallow tank}

A shallow tank is one with height to the radius ratio of less or equal to 1.5. The lumped mass model for this case is as shown in Fig. 2 It consists of a mass, $\mathrm{m}_{\mathrm{i}}$, moving with the rigid tank wall producing the impulsive force and a mass $m_{c}$, producing the convective force.

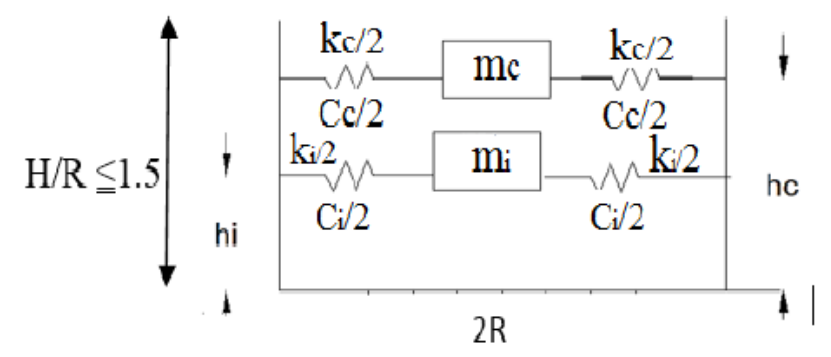

Figure 2 Shallow Tank- Lumped mass approach for H/R $\leq 1.5$ using Housner's method [26]

The heights of these masses were located on the basis of producing the correct moment about the base. These heights are designated by the letters $h_{i}$ and $h_{c}$ as shown in Fig. 2 . The heights $h_{i}$ and $h_{c}$ are used to calculate the bending moments about the base of the structure. The bending moment just above the base is resisted by the shell.

$$
\begin{aligned}
& \text { hi }=\frac{3}{8} \mathrm{H} \\
& \left.\mathrm{hc}=\mathrm{H} \mid 1-\frac{\cosh \left(\frac{1.84 \mathrm{H}}{\mathrm{R}}\right)-1}{1.84\left(\frac{\mathrm{H}}{\mathrm{R}}\right) \cdot \sinh \left(1.84\left(\frac{\mathrm{H}}{\mathrm{R}}\right)\right)}\right\rfloor \\
& \frac{\mathrm{m}_{\mathrm{i}}}{\mathrm{m}}=\frac{\tanh \left(0.866 \frac{\mathrm{D}}{\mathrm{h}}\right)}{0.866 \frac{\mathrm{D}}{\mathrm{h}}}
\end{aligned}
$$




$$
\frac{\mathrm{m}^{\mathrm{c}}}{\mathrm{m}}=0.23^{\frac{\tanh \left(3.68^{\frac{\mathrm{h}}{\mathrm{D}}}\right)}{\mathrm{D}}}
$$

\subsection{Force deformation behavior of isolation system (with and without Lead LRB).}

\subsubsection{Laminated Rubber Bearings}

The main components of laminated rubber bearings (LRB) are steel and rubber plates built in the alternate layers [28]. The restoring force developed in the bearing, $\mathrm{F}_{\mathrm{b}}$ is given by

$\mathrm{F}_{\mathrm{b}}=\mathrm{c}_{\mathrm{b}} \dot{\mathrm{x}}_{\mathrm{b}}+\mathrm{k}_{\mathrm{b}} \mathrm{x}_{\mathrm{b}}$

Where $\mathrm{c}_{\mathrm{b}}$ and $\mathrm{k}_{\mathrm{b}}$ are damping and stiffness of LRB system, respectively.

$$
\begin{aligned}
& \mathrm{k}_{\mathrm{b}}=\left(\frac{2 \pi}{\mathrm{T}_{\mathrm{b}}}\right)^{2}\left(\mathrm{M}+\mathrm{m}_{\text {Staging }}+\mathrm{m}_{\mathrm{b}}\right) \\
& \mathrm{c}_{\mathrm{b}}=2 \xi_{\mathrm{b}} \omega_{\mathrm{b}}\left(\mathrm{M}+\mathrm{m}_{\text {Staging }}+\mathrm{m}_{\mathrm{b}}\right)
\end{aligned}
$$

And $\omega_{\mathrm{b}}=\left(\frac{2 \pi}{T_{\mathrm{b}}}\right)$ is the isolation frequency.

\subsubsection{Lead-Rubber Bearings}

Lead rubber bearing are also called as N-Z bearings, same appearance as laminated rubber bearing containing a centrally a lead core used for energy dissipation and useful in a minor earthquake [29, 30]. For the present study, Wen's model [31] is used to characterize the hysteretic behavior of the N-Z bearings. The restoring force developed in the isolation bearing is given by.

$$
\mathrm{F}_{\mathrm{b}}=\mathrm{c}_{\mathrm{b}} \dot{\mathrm{x}}_{\mathrm{b}}+\alpha \mathrm{k}_{\mathrm{b}} \mathrm{x}_{\mathrm{b}}+(1-\alpha) \mathrm{F}_{\mathrm{y}} \mathrm{Z}
$$

Where $\mathrm{F}_{\mathrm{y}}$ is the yield strength of the bearing; $\alpha$ is an index which represent the ratio of post to pre-yielding stiffness; $\mathrm{k}_{\mathrm{b}}$ is the initial stiffness of the bearing; $\mathrm{c}_{\mathrm{b}}$ is the viscous damping of the bearing; and $\mathrm{Z}$ is the non-dimensional hysteretic displacement component satisfying the following non-linear first order differential equation expressed as

$$
\frac{q d Z}{d t}=-\beta\left|\dot{\mathrm{x}}_{b}\right| \mathrm{Z}|\mathrm{Z}|^{n-1}-\tau \dot{\mathrm{x}}_{b}|\mathrm{Z}|^{n}+\mathrm{A} \dot{\mathrm{x}}_{b}
$$

Where $\mathrm{q}$ is the yield displacement; dimensionless parameters $\beta, \tau, \mathrm{A}$ and $\mathrm{n}$ are selected such that predicted response from the model closely matches with the experimental results. The parameter $\mathrm{n}$ is an integer constant, which controls smoothness of transition from elastic to the plastic response. The N-Z system is characterized by the isolation period $\left(\mathrm{T}_{\mathrm{b}}\right)$, damping ratio $\left(\xi_{\mathrm{b}}\right)$ and normalized yield strength, i.e. Fy/W (where $\mathrm{W}=\mathrm{Mg}$ is the total weight of the building; and $g$ is the acceleration due to gravity). The other parameters of the $\mathrm{N}-\mathrm{Z}$ system are held constant with $\mathrm{q}=2.5 \mathrm{~cm}, \beta=\tau=0.5, \mathrm{~A}=1$ and $\mathrm{n}=2$.

\subsection{Newmark's step-by-step method of the model [32]}

Since the damping level in the isolator, supporting tower and vibrating liquid is very different, the equations of motion of the isolated elevated liquid storage tank cannot be solved using classical modal superposition technique. Alternatively, the equations of motion are solved in the incremental form using Newmark's step-by-step method assuming linear variation of acceleration over the small-time interval, $\Delta \mathrm{t}$. The equations of motion in the incremental form are written as.

$$
[\mathrm{m}][\ddot{\mathrm{x}}]+[\mathrm{c}]\{\dot{\mathrm{x}}\}+[\mathrm{k}]\{\mathrm{x}\}+\Delta \mathrm{F}=-[\mathrm{m}]\{\mathrm{r}\} \ddot{\mathrm{v}}_{\mathrm{g}}
$$


And expressed as below for Shallow Tank,

$$
\begin{aligned}
& {\left[\begin{array}{ccc}
\mathrm{m}^{\mathrm{c}} & \mathrm{m}^{\mathrm{c}} & \mathrm{m}^{\mathrm{c}} \\
\mathrm{m}_{\mathrm{c}} & \mathrm{M}+\mathrm{m}_{\mathrm{b}} & \mathrm{M}+\mathrm{m}_{\mathrm{b}} \\
\mathrm{m}_{\mathrm{c}} & \mathrm{M}+\mathrm{m}_{\mathrm{b}} & \mathrm{M}+3 \mathrm{~m}_{\mathrm{b}}
\end{array}\right]\left\{\begin{array}{l}
\ddot{x}_{\mathrm{x}} \\
\ddot{\mathrm{x}}_{\mathrm{t}} \\
\ddot{x}_{\mathrm{b}}
\end{array}\right\}+\left[\begin{array}{ccc}
\mathrm{Cc} & 0 & 0 \\
0 & \mathrm{C}_{\mathrm{t}} & 0 \\
0 & 0 & \mathrm{C}_{\mathrm{b}}
\end{array}\right]\left\{\begin{array}{c}
\dot{\mathrm{x}}^{\mathrm{c}} \\
\dot{\mathrm{x}}_{\mathrm{t}} \\
\dot{\mathrm{x}}_{\mathrm{b}}
\end{array}\right\}+\left[\begin{array}{ccc}
\mathrm{k}^{\mathrm{c}} & 0 & 0 \\
0 & \mathrm{k}_{\mathrm{t}} & 0 \\
0 & 0 & \mathrm{k}_{\mathrm{b}}
\end{array}\right]\left\{\begin{array}{l}
\mathrm{x}^{\mathrm{c}} \\
\mathrm{x}_{\mathrm{t}} \\
\mathrm{x}_{\mathrm{b}}
\end{array}\right\}+\Delta \mathrm{F}} \\
& =-\left[\begin{array}{ccc}
\mathrm{m}_{\mathrm{c}} & \mathrm{m}_{\mathrm{c}} & \mathrm{m}_{\mathrm{c}} \\
\mathrm{m}_{\mathrm{c}} & \mathrm{m}_{\mathrm{c}} & \mathrm{M}+\mathrm{m}_{\mathrm{b}} \\
\mathrm{m}_{\mathrm{c}} & \mathrm{M}+\mathrm{m}_{\mathrm{b}} & \mathrm{M}+3 \mathrm{~m}_{\mathrm{b}}
\end{array}\right]\left\{\begin{array}{l}
0 \\
0 \\
1
\end{array}\right\} \ddot{\mathrm{v}}_{\mathrm{g}}
\end{aligned}
$$

The displacement vector for the isolated model is expressed as $\{\mathrm{X}\}=\left\{\mathrm{X}_{\mathrm{c}}, \mathrm{X}_{\mathrm{i}}, \mathrm{X}_{\mathrm{t}}, \mathrm{X}_{\mathrm{b}}\right\}^{\mathrm{T}}, \mathrm{X}_{\mathrm{c}}=$ $\mathrm{u}_{\mathrm{c}}-\mathrm{u}_{\mathrm{t}}$, is the relative displacement of the sloshing mass, $\mathrm{x}_{\mathrm{i}}=\mathrm{u}_{\mathrm{i}}-\mathrm{u}_{\mathrm{t}}$, is the relative displacement of the impulsive mass; $\mathrm{x}_{\mathrm{t}}=\mathrm{u}_{\mathrm{t}}-\mathrm{u}_{\mathrm{b}}$ is the tower displacement (i.e. tower drift) and $\mathrm{x}_{\mathrm{b}}=\mathrm{u}_{\mathrm{b}}-\mathrm{u}_{\mathrm{g}}$, is the relative bearing displacement. $\Delta \mathrm{F}$ is restoring force vector which is given as

$\Delta \mathrm{F}=\left\{\begin{array}{c}0 \\ 0 \\ (1-\alpha) \mathrm{F}_{\mathrm{y}} \Delta \mathrm{Z}\end{array}\right\}$

Fallowing the assumption of linear variation of acceleration over the time interval $\Delta t$. Stiffness $\mathrm{k}_{\mathrm{b}}$ and damping $\mathrm{C}_{\mathrm{b}}$ of isolation are defined as $\Delta \mathrm{t}$ incremental vectors $\{\Delta \ddot{\mathrm{x}}\}$ and $\{\Delta \dot{\mathrm{x}}\}$ are given by

$$
\begin{array}{r}
\{\Delta \ddot{\mathrm{x}}\}=\mathrm{a}_{0}\{\Delta \mathrm{x}\}+\mathrm{a}_{1}\{\dot{\mathrm{x}}\}^{\mathrm{t}}+\mathrm{a}_{2}\{\ddot{\mathrm{x}}\}^{\mathrm{t}} \\
\{\Delta \dot{\mathrm{x}}\}=\mathrm{b}_{0}\{\Delta \mathrm{x}\}+\mathrm{b}_{1}\{\dot{\mathrm{x}}\}^{\mathrm{t}}+\mathrm{b}_{2}\{\ddot{\mathrm{x}}\}^{\mathrm{t}}
\end{array}
$$

Where, $\mathrm{a}_{0}=\frac{6}{\Delta \mathrm{t}^{2}} ; \mathrm{a}_{1}=\frac{6}{\Delta \mathrm{t}} ; \mathrm{a}_{2}=-3 ; \mathrm{b}_{0}=\frac{3}{\Delta \mathrm{t}} ; \mathrm{b}_{1}=-3 ; \mathrm{b}_{2}=-\frac{\Delta \mathrm{t}}{2}$ the subscript denotes the time. Substituting the values from equation (2.8) and (2.9) in the incremental form of equation of motion, the equation of motion can be written as.

$$
\begin{aligned}
{\left[\mathrm{a}_{0}[\mathrm{~m}]+\mathrm{b}_{0}[\mathrm{c}]+[\mathrm{k}]\right]\{\Delta \mathrm{x}\} } & \\
= & \left([\mathrm{m}]\{\mathrm{r}\} \ddot{\mathrm{v}}_{\mathrm{g}}-[\mathrm{m}]\left(\mathrm{a}_{1}\{\dot{\mathrm{x}}\}^{\mathrm{t}}+\mathrm{a}_{2}\{\ddot{\mathrm{x}}\}^{\mathrm{t}}\right)-[\mathrm{c}]\left(\mathrm{b}_{1}\{\dot{\mathrm{x}}\}^{\mathrm{t}}+\mathrm{b}_{2}\{\ddot{\mathrm{x}}\}^{\mathrm{t}}\right)\right) \\
& -(\Delta \mathrm{F})
\end{aligned}
$$

After solving for incremental displacement vector from equation (2.9) the incremental velocity vector is obtained from the equation (2.8). The restoring force vector at time $t+\Delta t$ is obtained by

$$
\{\mathrm{F}\}^{t+\Delta t}=\{\mathrm{F}\}^{t}+\{\Delta \mathrm{F}\}
$$

In order to estimate the force vector $\{\Delta \mathrm{F}\}$ the incremental hysteretic displacement, $\mathrm{Z}$ is determined by solving first order differential equation (3.1)

$$
\frac{q d Z}{d t}=-\beta\left|\dot{\mathrm{x}}_{b}\right| \mathrm{Z}|\mathrm{Z}|^{n-1}-\tau \dot{\mathrm{x}}_{b}|\mathrm{Z}|^{n}+\mathrm{A} \dot{\mathrm{x}}_{b}
$$

In order to estimate the force vector $\{\Delta \mathrm{F}\}$ the incremental hysteretic displacement, $\Delta \mathrm{Z}$ is determined by incremental solution techniques using equation (3.2) with the help of third order Runga-Kutta method. The force deformation behavior of the elastomeric bearing can be modeled by properly selecting the parameters $\mathrm{Q}_{\mathrm{y}}, \mathrm{q}, \alpha, \beta, \tau, \mathrm{n}$ and $\mathrm{A}$. The step-by-step computational procedure is as below.

- Assume an initial value of $\Delta \mathrm{Z}=0$ at first iteration value $\mathrm{j}=1$.

- Substitute the value $\Delta \mathrm{Z}$ in equation (2.6) and then putting the value of $\Delta \mathrm{F}$ in equation (2.9) to obtain value of $\Delta \mathrm{x}$.

- From equation (2.8) the velocity vector is determined at time step $\mathrm{t}+\Delta \mathrm{t}$

- Compute the revised value of $\Delta \mathrm{Z}$ using the third order Runga Kutta method that is expressed as 
$\Delta \mathrm{Z}=\frac{\mathrm{K}^{0}+3 \mathrm{~K}^{2}}{4}$

Where, $\mathrm{K}_{0}, \mathrm{~K}_{2}$ are Runga-Kutta constants.

$\mathrm{k}_{0}=\Delta \mathrm{tf}\left(\dot{\mathrm{x}}_{\mathrm{b}, \mathrm{z}}^{\mathrm{t}}\right)$

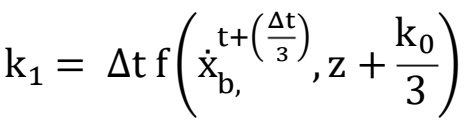

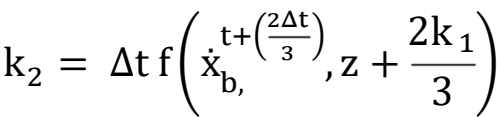

Repeat Step (ii) \& (iv) and iterate till following convergence criteria is satisfied.

$\frac{\Delta \mathrm{Z}_{\mathrm{j}+1}-\Delta \mathrm{Z}_{\mathrm{j}}}{Z_{m}} \leq$ tolerence

Where, subscript $\mathrm{j}$ denotes the iteration number; $Z_{m}$ is the maximum value of hysteretic displacement of the bearing is expressed by.

$Z_{m}=\sqrt{\frac{A}{\beta+\tau}}$

$\mathrm{k}_{\mathrm{b}}=\left(\frac{2 \pi}{\mathrm{T}_{\mathrm{b}}}\right)^{2}\left(\mathrm{M}+\mathrm{m}_{\text {Staging }}+\mathrm{m}_{\mathrm{b}}\right)$

$c_{b}=2 \xi_{b} \omega_{b}\left(M+m_{\text {Staging }}+m_{b}\right)$

Where, $\mathrm{T}_{\mathrm{b}}$ is the time period of isolation system $=2 \mathrm{sec}$ and $4 \mathrm{sec}$ and $\xi_{\mathrm{b}}$ damping ratio of isolation system $=0.1$.After obtaining the acceleration vector, the base shear is computed, which is directly proportional to earthquake forces transmitted to the tank is expressed as,

$\mathrm{f}_{\mathrm{b}}=\mathrm{m}_{\mathrm{c}} \ddot{\mathrm{v}}_{\mathrm{c}}+\mathrm{m}_{\mathrm{i}} \ddot{\mathrm{v}}_{\mathrm{i}}+\left(\mathrm{m}_{\mathrm{b}}\right) \ddot{\mathrm{v}}_{\mathrm{t}} \quad$ (For non - isolated tank model)

$\mathrm{f}_{\mathrm{b}}=\mathrm{m}_{\mathrm{c}} \ddot{\mathrm{v}}_{\mathrm{c}}+\mathrm{m}_{\mathrm{i}} \ddot{\mathrm{v}}_{\mathrm{i}}+\left(\mathrm{m}_{\mathrm{b}}\right) \ddot{\mathrm{v}}_{\mathrm{t}}+2\left(\mathrm{~m}_{\mathrm{b}}\right) \ddot{\mathrm{v}}_{\mathrm{b}} \quad$ (For isolated tank model)

\subsection{Verification of the Newark's step by step iteration procedure}

To perform the verification of the proposed, the results of water free surface displacement obtained from the numerical model, is compared with experimental results. The test tank was selected for verification process has circular shape with dimension of $0.19 \times 0.3 \mathrm{~m}$ in diameter and height, respectively. The water height in the tank is considered $0.125 \mathrm{~m}$. The response of the circular tank was studied under the harmonic sinusoidal excitation. To prevent seismic damage of water tank natural frequency must be calculated, then the seismic frequency calculated via subjected to seismic wave should be difference of natural frequency. The test tank was excited with horizontal forced frequencies bigger than the first fundamental frequency of contained liquid which is obtained from the equation (4.2). The seismic wave motion is given by equation (4.3): 


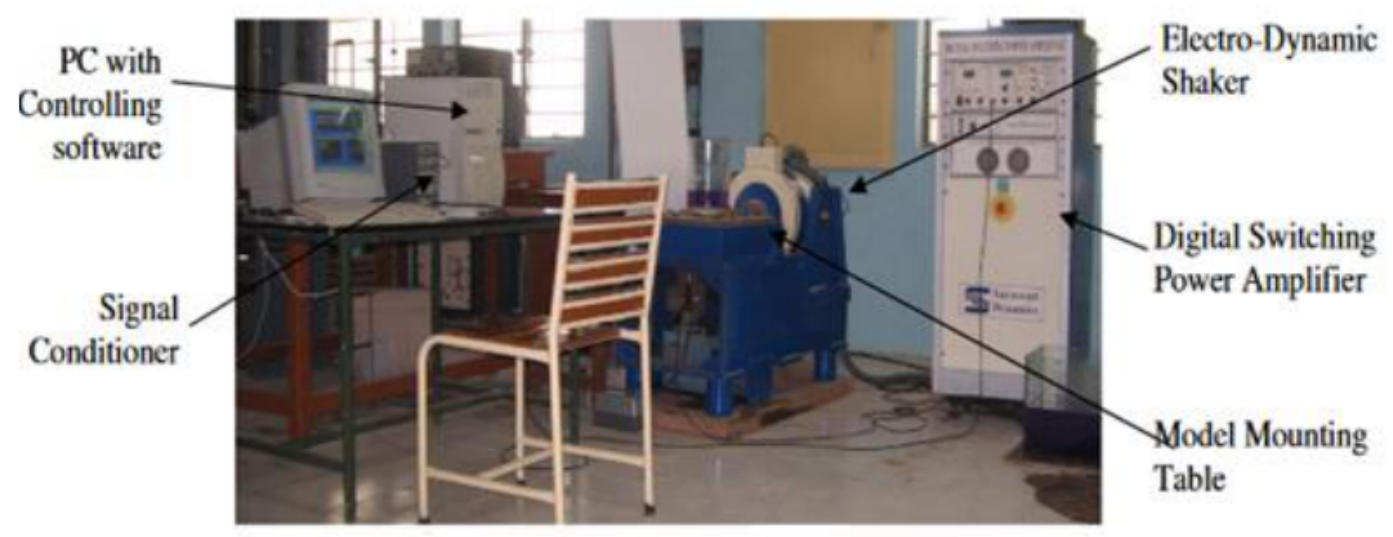

Figure 3.Experimental set-up-shake table test

For the circular and rectangular tanks, the first sloshing frequency is given by Eqn. (Housner, 1963):

For circular tanks

$$
\begin{aligned}
& \omega_{n}=\frac{1}{2 n} \sqrt{\frac{3.68 \mathrm{~g} \tanh \left(3.68 \frac{\mathrm{h}}{\mathrm{D}}\right)}{D}} \\
& \chi(\mathrm{t})=\mathrm{D} \sin \omega_{t}
\end{aligned}
$$

In above formula $\mathrm{D}$ is maximum horizontal amplitude and $\omega$ is horizontal forced frequency which were considered to $0.0012 \mathrm{~m}$ and $6.221 \mathrm{HZ}, \mathrm{n}$ is number of oscillation modes. Natural frequency of first mode of experimental tank is equal to $2.19 \mathrm{HZ}$.

The Mann-Whitney analysis showed, there is no significant difference between the numerical and experimental data: $(\mathrm{P}-\mathrm{value}=0.319)>0.01$. Comparison between experimental and numerical results on verification processes are shown in Fig. 4.

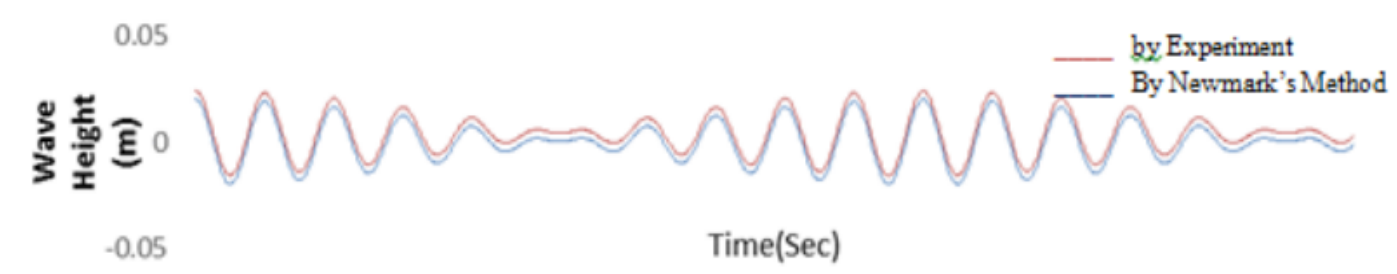

Figure. 4. Comparison between FEM results of sloshing wave height and experimental measurements

\subsection{Earthquake Ground Motion}

A Imperial Valley, 1940,El-Centro strong motion stations that recorded earthquake motions with peak ground accelerations larger than $0.21 \mathrm{~g}$ selected for dynamic analysis; this records is shown in Figure. Due to the voluminous and time-consuming model analysis, the intensive volatility areas of the earthquake records is used for calculation.

\begin{tabular}{|c|c|c|c|c|c|c|}
\hline Sr.No. & Record & Notation & Component & Direction & PGA & Magnitude \\
\hline \multirow{4}{*}{1} & $\begin{array}{c}\text { Imperial } \\
\text { Valley, } \\
1940, \text { El- } \\
\text { Centro }\end{array}$ & El-Centro & Normal (N) & $\mathrm{X}$ & 0.26 & 6.95 \\
\hline
\end{tabular}




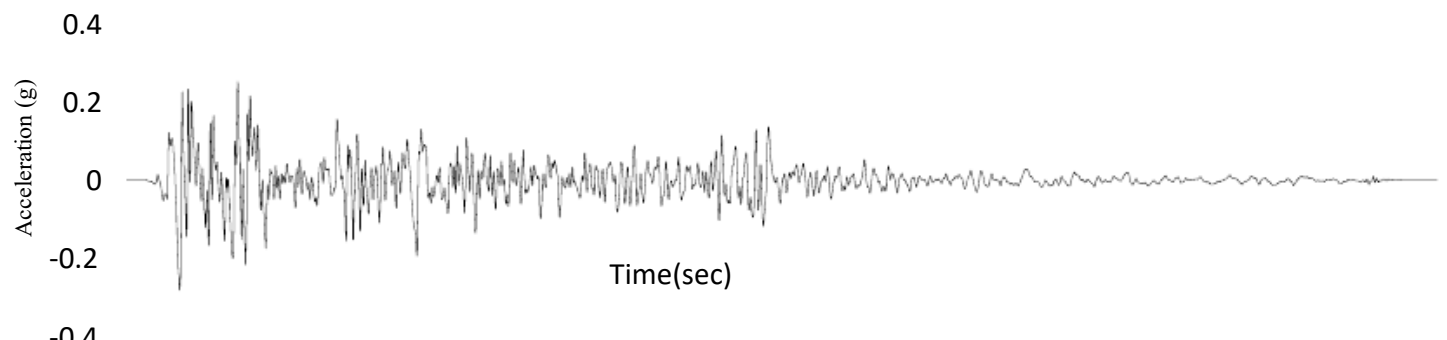

$-0.4$

Figure 5 Imperial Valley, 1940, El-Centro strong motion stations that recorded earthquake.

\subsection{Numerical Analysis of water tank (50 kL)}

Sloshing characteristics of a tank contain natural frequencies and mode shapes that are important parameters in the analysis. The determination of these parameters can be very useful in describing the tank's behavior. Modal analysis is used to determine these characters and original mode of structure in horizontal and vertical directions. Convective and impulsive modes are the most important vibration modes that have the maximum of mass contribution effects. This analysis could be a starting point for other analyses such as time history analysis. The effect of non-classical damping on the response of base isolated tanks are investigated. For the present study the component S00E of Imperial Valley (1940) earthquake ground motion is used to investigate the response of the tank. A 50kl, tank with varying staging height $12 \mathrm{~m}, 20 \mathrm{~m}$, $28 \mathrm{~m}$ is analyzed.

The peak response of the tanks obtained by the exact and modal analysis are compared in Table 1 under El-Centro earthquake motion. The result shows, the peak response quantities such as base shear $\left(\mathrm{f}_{\mathrm{s}} / \mathrm{w}\right)$, displacement $\left(\mathrm{x}_{\mathrm{c}}\right)$ and $\left(\mathrm{x}_{\mathrm{b}}\right)$ are obtained by the modal analysis. Results indicate that the effect of non-classical damping are insignificant and the peak seismic response of isolated tanks can be accurately estimated by modal analysis.

Table 1 Peak Response of Base Isolated Shallow and Slender Tank

\begin{tabular}{|c|c|c|c|c|c|c|c|c|c|c|}
\hline \multirow[t]{2}{*}{$\begin{array}{c}\text { Earthq- } \\
\text { uakes }\end{array}$} & \multirow[t]{2}{*}{$\begin{array}{c}\text { Capacity } \\
\text { of tank }\end{array}$} & \multirow[t]{2}{*}{$\begin{array}{c}\text { Height } \\
\text { of } \\
\text { staging }\end{array}$} & \multicolumn{4}{|c|}{$\begin{array}{c}\text { Exact response } \\
\text { Isolated } \\
\text { (Lead-LRB) }\end{array}$} & \multicolumn{4}{|c|}{$\begin{array}{l}\text { Modal response } \\
\text { Isolated } \\
\text { (Lead-LRB) }\end{array}$} \\
\hline & & & $\begin{array}{c}\mathbf{x}_{\mathbf{c}} \\
(\mathbf{c m})\end{array}$ & $\begin{array}{c}\mathbf{x}_{\mathbf{t}} \\
(\mathbf{c m})\end{array}$ & $\begin{array}{c}\mathbf{x}_{\mathrm{b}} \\
(\mathrm{cm})\end{array}$ & $\mathbf{f}_{\mathbf{s}} / \mathbf{W}$ & $\begin{array}{c}\mathbf{x}_{\mathbf{c}} \\
(\mathrm{cm})\end{array}$ & $\begin{array}{c}\mathbf{x}_{\mathbf{t}} \\
(\mathbf{c m})\end{array}$ & $\begin{array}{c}\mathbf{x}_{\mathbf{b}} \\
(\mathrm{cm})\end{array}$ & $\mathbf{f}_{\mathrm{s}} / \mathbf{W}$ \\
\hline \multirow{6}{*}{$\begin{array}{l}\text { El- } \\
\text { Centro } \\
1940 \\
\text { earthq- } \\
\text { uake }\end{array}$} & \multirow{3}{*}{$\begin{array}{l}50 \mathrm{kl} \\
\left(\mathrm{T}_{\mathrm{b}}=2\right. \\
\text { Sec and } \\
\left.\xi_{\mathrm{b}}=0.1\right)\end{array}$} & $12 \mathrm{~m}$ & 42.66 & 0.59 & 9.23 & 0.041 & 42.93 & 0.50 & 9.19 & 0.039 \\
\hline & & $20 \mathrm{~m}$ & 35.27 & 0.45 & 9.29 & 0.032 & 35.88 & 0.33 & 9.29 & 0.034 \\
\hline & & $28 \mathrm{~m}$ & 55.7 & 0.44 & 6.48 & 0.029 & 54.7 & 0.35 & 6.46 & 0.03 \\
\hline & \multirow{3}{*}{$\begin{array}{l}50 \mathrm{kl} \\
\left(\mathrm{T}_{\mathrm{b}}=4\right. \\
\text { Sec and } \\
\left.\xi_{\mathrm{b}}=0.1\right)\end{array}$} & $12 \mathrm{~m}$ & 59.1 & 1.19 & 9.6 & 0.04 & 59.8 & 1.1 & 9.76 & 0.042 \\
\hline & & $20 \mathrm{~m}$ & 60.7 & 0.69 & 13.8 & 0.03 & 59.8 & 0.59 & 13.8 & 0.035 \\
\hline & & $28 \mathrm{~m}$ & 55.1 & 0.27 & 23.2 & 0.03 & 54.2 & 0.2 & 23.2 & 0.03 \\
\hline
\end{tabular}

\subsection{Time $H$ Analysis of water $\operatorname{tank}(50 \mathrm{~kL})$}

For complete investigation of seismic behavior of liquid storage tanks (50 kL), response quantities are base shear, displacement of the convective, impulsive and isolation system. The response of the isolation system is compared with the corresponding response of the tank without an isolation system. The response quantities of interest are base shear (measure at bottom of the foundation level), ( $\mathrm{W}=\mathrm{Mg})$, sloshing displacement $\left(\mathrm{X}_{\mathrm{c}}\right)$, impulsive displacement $\left(\mathrm{X}_{\mathrm{i}}\right)$, isolator displacement $\left(\mathrm{x}_{\mathrm{b}}\right)$. Table 2 and figure. 6 shows the comparative study of the peak response of isolated elevated shallow against corresponding non-isolated tanks under Imperial 
Valley (1940), The isolation parameters considered are $\mathrm{T}_{\mathrm{b}}=2 \mathrm{sec}, 4 \mathrm{sec} \& \xi_{\mathrm{b}}=0.1$ (Shallow Tank). The above results indicate that isolation reduces the base shear significantly, while sloshing displacement increases with increase in height of tank.. The reduction in base shear is comparatively more in short staging height tanks, also there is reduction in base shear in $20 \mathrm{~m}$ and $28 \mathrm{~m}$ staging height tank. That's indicated, the reduction in base shear is slightly more in the tank with stiff framed structure, also the isolation techniques is also effective in $20 \mathrm{~m}$ and $28 \mathrm{~m}$ staging height tank. Table 2 indicates that tower drift is reduced due to isolation, significantly and this is more pronounced when tower structure is comparatively rigid. It is also observed that increased flexibility of tower structure transmits fewer earthquake forces, but it increases tower drift significantly. This implies that for stiff tower structures the reduction in the response achieved is more in comparisons to flexible tower structures. The peak sloshing displacement is increased significantly with an increase in height of staging in both the tanks.

Table 2 Peak Response of Elevated Tank (Shallow Tank)

\begin{tabular}{|c|c|c|c|c|c|c|c|c|}
\hline \multirow[b]{3}{*}{ Earthquake } & \multirow{3}{*}{$\begin{array}{c}\text { Capacity } \\
\text { of tank }\end{array}$} & \multirow{3}{*}{$\begin{array}{c}\text { Height } \\
\text { of } \\
\text { staging }\end{array}$} & \multirow{3}{*}{$\begin{array}{c}\text { Type } \\
\text { of } \\
\text { Tank }\end{array}$} & \multirow{2}{*}{\multicolumn{4}{|c|}{$\begin{array}{c}\mathrm{T}_{\mathrm{b}}=2 \mathrm{sec}, \xi_{\mathrm{b}}=0.1 \\
\text { Shallow tank }\end{array}$}} & \multirow{3}{*}{$\begin{array}{c}\% \\
\text { Reduction } \\
\text { Base shear }\end{array}$} \\
\hline & & & & & & & & \\
\hline & & & & $\mathbf{f}_{\mathbf{b}} / \mathbf{W}$ & $\begin{array}{c}\mathbf{X}_{\mathbf{c}} \\
(\mathbf{c m})\end{array}$ & $\begin{array}{c}\mathbf{X t} \\
(\mathbf{c m})\end{array}$ & $\begin{array}{c}\mathbf{x} \mathbf{b} \\
(\mathbf{c m})\end{array}$ & \\
\hline \multirow{9}{*}{$\begin{array}{l}\text { Imperial } \\
\text { Valley } \\
(1940)\end{array}$} & \multirow{9}{*}{$50 \mathrm{kl}$} & \multirow{3}{*}{$12 \mathrm{~m}$} & Non-isolated & 0.17 & 30.47 & 2.89 & & \\
\hline & & & $\begin{array}{l}\text { Isolated } \\
\text { (LRB) }\end{array}$ & 0.042 & 43.84 & 0.6 & 8.56 & 75.08 \\
\hline & & & $\begin{array}{l}\text { Isolated } \\
\text { (Lead-LRB) }\end{array}$ & 0.041 & 35.37 & 0.59 & 9.23 & 75.08 \\
\hline & & \multirow{3}{*}{$20 \mathrm{~m}$} & Non-isolated & 0.098 & 35.63 & 2.95 & & \\
\hline & & & $\begin{array}{l}\text { Isolated } \\
\text { (LRB) }\end{array}$ & 0.035 & 59.42 & 0.48 & 9.21 & 63.84 \\
\hline & & & $\begin{array}{l}\text { Isolated } \\
\text { (Lead-LRB) }\end{array}$ & 0.032 & 35.27 & 0.45 & 9.29 & 63.84 \\
\hline & & \multirow[b]{3}{*}{$28 \mathrm{~m}$} & Non-isolated & 0.085 & 35.86 & 2.92 & & \\
\hline & & & $\begin{array}{l}\text { Isolated } \\
\text { (LRB) }\end{array}$ & 0.03 & 60.43 & 0.79 & 6.48 & 63.56 \\
\hline & & & $\begin{array}{l}\text { Isolated } \\
\text { (Lead-LRB) }\end{array}$ & 0.029 & 61.14 & 0.44 & 6.48 & 63.56 \\
\hline
\end{tabular}

\begin{tabular}{|c|c|c|c|c|c|c|c|c|}
\hline \multirow[b]{3}{*}{ Earthquake } & \multirow{3}{*}{$\begin{array}{c}\text { Capacity of } \\
\operatorname{tank}\end{array}$} & \multirow{3}{*}{$\begin{array}{c}\text { Height of } \\
\text { staging }\end{array}$} & \multirow{3}{*}{$\begin{array}{c}\text { Type } \\
\text { of } \\
\text { Tank }\end{array}$} & \multicolumn{4}{|c|}{$T_{b}=4 \sec , \xi_{b}=0.1$} & \multirow{3}{*}{$\begin{array}{c}\% \\
\text { Reduction } \\
\text { Base shear }\end{array}$} \\
\hline & & & & \multicolumn{4}{|c|}{ Shallow tank } & \\
\hline & & & & $\mathbf{f} / \mathbf{W}$ & $\begin{array}{l}\mathbf{X}_{\mathrm{c}} \\
(\mathrm{cm})\end{array}$ & $\begin{array}{l}\mathrm{Xt} \\
(\mathrm{cm})\end{array}$ & $\begin{array}{l}\mathbf{X b} \\
(\mathrm{cm})\end{array}$ & \\
\hline \multirow{9}{*}{$\begin{array}{l}\text { Imperial Valley } \\
(1940)\end{array}$} & \multirow{9}{*}{$50 \mathrm{kl}$} & \multirow{3}{*}{$12 \mathrm{~m}$} & Non-isolated & 0.17 & 30.51 & 2.89 & & \\
\hline & & & $\begin{array}{l}\text { Isolated } \\
\text { (LRB) }\end{array}$ & 0.0425 & 60.73 & 1.19 & 9.62 & 75.00 \\
\hline & & & $\begin{array}{l}\text { Isolated } \\
\text { (Lead-LRB) }\end{array}$ & 0.0425 & 59.16 & 1.19 & 9.62 & 75.00 \\
\hline & & \multirow{3}{*}{$20 \mathrm{~m}$} & Non-isolated & 0.098 & 35.63 & 2.95 & & \\
\hline & & & Isolated & 0.0358 & 55.12 & 0.69 & 14.38 & 63.42 \\
\hline & & & $\begin{array}{l}\text { Isolated } \\
\text { (Lead-LRB) }\end{array}$ & 0.0358 & 60.73 & 0.69 & 13.80 & 63.42 \\
\hline & & \multirow{3}{*}{$28 \mathrm{~m}$} & Non-isolated & 0.085 & 35.83 & 2.95 & & \\
\hline & & & Isolated & 0.0309 & 55.12 & 0.27 & 22.88 & 63.57 \\
\hline & & & $\begin{array}{l}\text { Isolated } \\
\text { (Lead-LRB) }\end{array}$ & 0.0309 & 55.12 & 0.27 & 23.28 & 63.57 \\
\hline
\end{tabular}



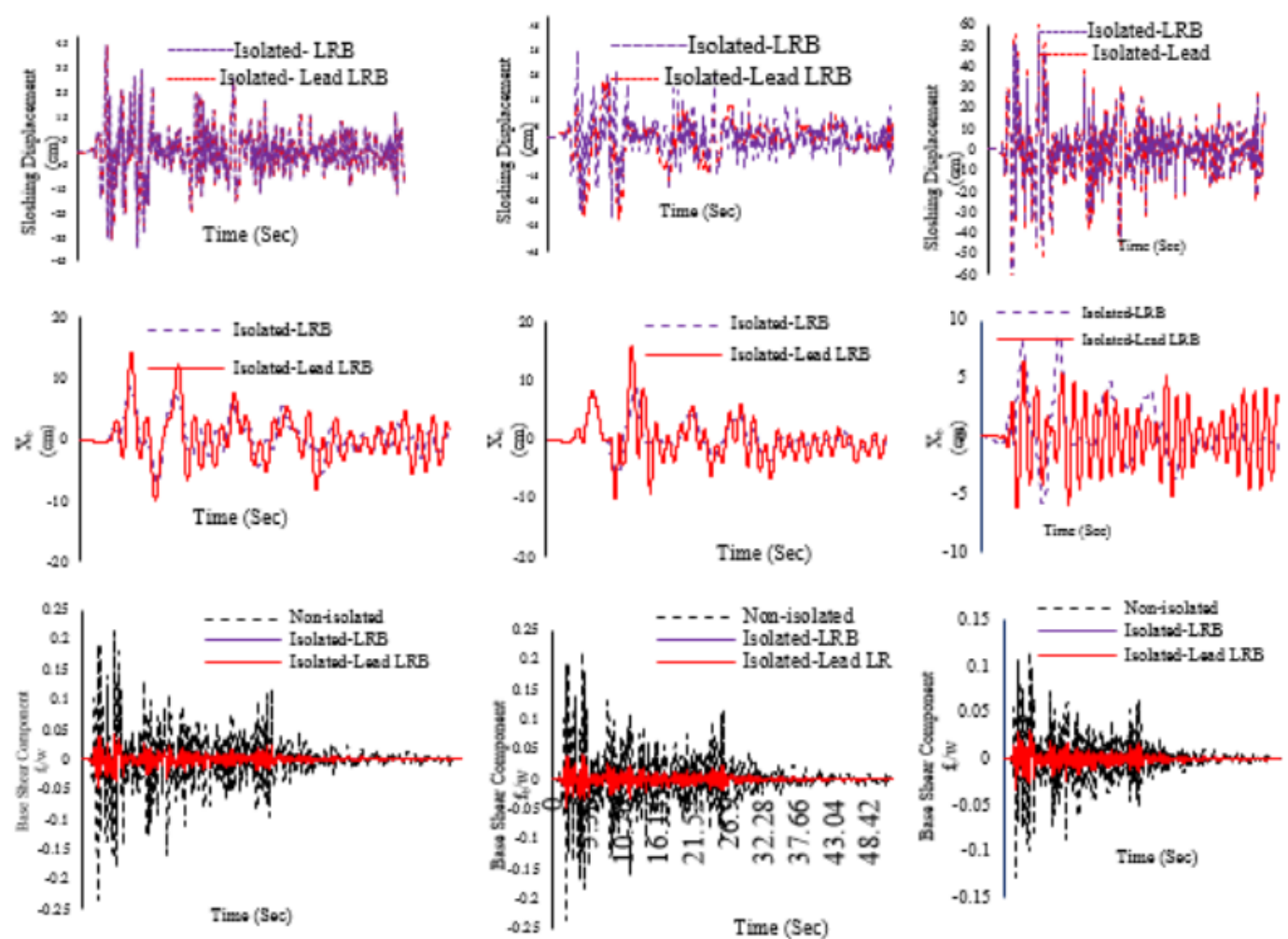

Figure.6 Time Variation Response Quantities of $50 \mathrm{kl}(12 \mathrm{~m}, 20 \mathrm{~m}, 28 \mathrm{~m})$ Staging Height Shallow Tank Due to Imperial Valley, 1940 Earthquake $\left(\mathrm{T}_{\mathrm{b}}=2 \mathrm{Sec}, \mathrm{g}_{\mathrm{h}}=0.1, \mathrm{~F} 0=0.05\right)$.

\section{CONCLUSIONS}

Some of the past and present research studies on seismic response analysis for liquid storage tanks were reviewed. In addition, Newark's step by step iteration procedure is used for solving the complicated equation of motion for fixed and bases isolated liquid storage tanks under Xdirection horizontal components of real earthquake ground motions. The dynamic analysis to evaluate seismic response sloshing and base shear was proposed and validated by the experimental results. The conclusions obtained are summarized as follows:

- A verification of Newark's step by step iteration procedure was performed, the experimental and numerical values were compared with statistical analysis based on Mann-Whitney rules showed there is no significant difference between the numerical and experimental data:

- the influence of isolation damping on the seismic response of shallow tank (50 KL) with varying staging height which shows that the base shear, tower drift reduces for effective damping $\xi_{\mathrm{b}}=0.1$. Also, it has been found that reduction in base shear is significantly decreases while sloshing displacement gradually increases with increase in the height of tank.

- The influence of time period of isolation system on response of shallow tank investigated. It is observed that due to increase of isolation period base shear is reduced significantly because of increased flexibility of the isolation system transmit less acceleration to liquid container, hence less dynamic forces are generated. The sloshing displacement marginally increases with increase of time period and further increase in time period increase the sloshing displacement. 


\section{REFERENCES}

[1] Vosoughifar HR, Naderi MA. Seismic behavior of isolated liquid tanks subjected to farfield earthquake, international conference on civil engineering, architecture and urban sustainable development. 2013; 15.

[2] Housner GW. Dynamic behavior of water tanks. Bulletin of the Seismological Society of America. 1963; 53:381-7.

[3] Haroun MA. Vibration studies and test of liquid storage tanks. Earthquake Engineering and Structural Dynamics. 1983; 11:179-206.

[4] Haroun MA, Housner GW. Seismic design of liquid storage tanks. Journal of Technical Councils, ASCE. 1981; 107:191-207.

[5] Chen JZ, Kianoush MR. Generalized SDOF system for seismic analysis of concrete rectangular liquid storage tanks, Engineering Structures. 2009; 31:2426-2435.

[6] Kianoush MR, Ghaemmaghami AR. The effect of earthquake frequency content on the seismic behavior of concrete rectangular liquid tanks using the finite element method incorporating soilstructure interaction, Engineering Structures. 2011; 33:2186-2200.

[7] Kelly JM. A seismic base isolation: a review and bibliography, Soil Dynamics and Earthquake Engineering. 1986; 5:202-216.

[8] Chalhoub MS, Kelly JM. Shake table test of cylindrical water tanks in base-isolated structures, Journal of Engineering Mechanics, American Society of Civil Engineers. 1990; 116(7):14511472 .

[9] Kim NS, Lee DG. Pseudo-dynamic test for evaluation of seismic performance of base isolated liquid storage tanks, Engineering Structures. 1995; 17(3):198-208.

[10] Liang B, Tang J-X. Vibration studies of base-isolated liquid storage tanks. Computers and Structures. 1994; 52:1051-9.

[11] Malhorta PK. Method for seismic base-isolation of liquid storage tanks. Journal of Structural Engineering, ASCE. 1997;123(1):113-6.

[12] Malhorta PK. New method for seismic isolation of liquid storage tanks. Earthquake Engineering and Structural Dynamics. 1997;26(8):839-47.

[13] Shrimali MK, Jangid RS. Non-linear seismic response of base isolated liquid storage tank to bidirectional excitation. Nuclear Engineering and Design. 2002;217:1-20.

[14] Shrimali MK, Jangid RS. Seismic response of liquid storage tanks isolated by sliding bearings. Engineering and Structure. 2002;24:909-21.

[15] Shekari MR, Khaji N, Ahmadi MT. On the seismic behavior of cylindrical base-isolated liquid storage tanks excited by long-period ground motions. Soil Dynamics and Earthquake Engineering. 2010;968-980.

[16] Mirzabozorg H, Hariri-Ardebili MA, Nateghi-AR. Seismic Behavior of Three Dimensional Concrete Rectangular Containers Including Sloshing Effects, Coupled System Mechanics. 2012;1(1):79-98.

[17] Mirzabozorg H, Hariri-Ardebili MA, Nateghi-AR. Free Surface Sloshing Effect on Dynamic Response of Rectangular Storage Tanks, American Journal of Fluid Dynamics. 2012;2(4):2330 .

[18] Goudarzi HR. Seismic Analysis of Hydrodynamic Sloshing Force on Storage Tanks Roofs earthquake Spectra. Earthquake Engineering Research Institute; 2009.

[19] PEER Strong Motion Database. University of California. Available: http. //peer.berkeley.edu/.

[20] Theory manual of ANSYS, a general purpose finite element package; 2013. 
[21] Iranian code on analysis and design criteria of ground water tanks, (Code No. 123).

[22] Soni DP, Mistryb BB, Panchal VR. Double variable frequency pendulum isolator for seismic isolation of liquid storage tanks. Nuclear Engineering and Design. 2011; 241:700-713.

[23] Haroun, M.A., Housner, G.W., Dynamics Characteristics of Liquid Storage Tanks. Journal of Engineering Mechanics, ASCE, 108(EM5), 783(1982).

[24] El Damatty,A.A.,Korol,R.M.and Mirza,F.A.,Stability of Elevated Liquid Filled Conical Tanks Under Seismic Loading Part-II -Application, Earthquake Engineering And Structural Dynamics,26,1209(1997).

[25] Malhotra, P.K., Base Uplifting Analysis of Flexibly Supported Liquid Storage Tanks, Earthquake Engineering And Structural Dynamics, 24, 1591(1995).

[26] Peek, R and El Bkaily ,M.,Plastic Buckling of Unanchored Roofed Tanks Under Dynamic Loads, Journal of Engineering Mechanics DIV., 124(6), 648(1998).

[27] Konstantin Meslouris, Structural Dynamics; Models, Method and Experiment, Erst \& Sohn, 2000 .

[28] Datta T.K. "Seismic analysis of structures," John Willey \& Sons (Asia) Pte.Ltd. ISBN 978-0470-82461-0 (HB).

[29] Naeim Farzad \& Kelly J. M. "Design of Seismic Isolated Structures (From Theory to Practice)", John Willey \& Sons (Asia) Pte.Ltd.

[30] Simo J.C., Kelly J.M, the Analysis of Multi-Layer Elastomeric Bearings. Journal of Appl. Mech, ASME 1984; 51:256-62.

[31] Skinner R.I., Kelly J.M., Heine A.J., Hysteretic Damper for Earthquake Resistant Structures. Earthquake Eng. Struct. Dyn 1975; 3:287.

[32] Rao, S.S., Mechanical Vibration, Prentice Hall (2004).

[33] M. V. Kulkarni, C. P. Pise, C. M. Deshmukh, S. S. Kadam, G. D. Lakade and Y. P. Pawar, Effect of Seismic Forces and Wind on Base Shear of HighRise Buildings By Is 1893: Part- I \& Is 875: Part 3, International Journal of Civil Engineering and Technology, 10(10), 2018, pp. (1444)-(1453).

[34] RahmathullaNoufal .E, Parametric Investigation of the Effect on Base Shear of Multistoried Reinforced Concrete Frames, International Journal of Civil Engineering and Technology (IJCIET), Volume 5, Issue 7, July (2014), pp. 81-88 